\title{
Recurrent massive haemoperitoneum associated with ruptured corpus luteum in women with congenital afibrinogenemia; case report
}

\author{
Konjenital afibrinojenemili hastada korpus luteum rüptürüne \\ bağlt tekrarlayan masif hemoperitoneum olgusu
}

\author{
Özhan Özdemir, Mustafa Erkan Sarı, Aslıhan Kurt, Ertuğrul Şen, Cemal Reşat Atalay \\ Ankara Numune Education and Research Hospital, Clinic of Gynecology and Obstetrics, Ankara, Turkey
}

\begin{abstract}
Massive hemoperitoneum secondary to ruptured corpus luteum is a rare but serious and life-threatening complication for women with congenital bleeding disorders and may lead to surgical interventions and even oophorectomy. Congenital afibrinogenemia is a rare inherited coagulation disorder. As it can be asymptomatic, its clinical manifestations vary from minimal tendency of bleeding to life-threatening bleedings. Intraabdominal bleeding due to ovulation is very rare in these patients and only a few cases of corpus luteum rupture and hemoperitoneum in afibrinogenemic patients have been described. We report on a 28-year-old woman with congenital afibrinogenemia with recurrent massive intraabdominal bleeding due to ovulation as the presenting clinical sign. The first episode was managed with fresh frozen plasma, cryoprecipitate and blood transfusions; exploratory laparotomy and excision of the ruptured follicle was performed at the second episode; the third episode was managed with fresh frozen plasma, cryoprecipitate and blood transfusions; exploratory laparotomy and right salphingooopherectomy was performed at the fourth episode; fifth episode was managed with fresh frozen plasma, cryoprecipitate and blood transfusions. Conservative management is crucial for patients with congenital bleeding disorders. These case demonstrate that preservation of ovarian function is possible with a conservative approach and recurrent episodes may be prevented by suppression of ovulation. J Turk Soc Obstet Gynecol 2014:4:242-5
\end{abstract}

Key Words: Congenital afibrinogenemia, ruptured corpus luteum, hemoperitoneum

Conflict of Interest: The authors reported no conflict of interest related to this article.

\section{Özet}

Konjenital kanama bozukluğu olan kadınlarda, korpus luteum rüptürüne bağll masif hemoperitoneum nadir görülen ancak cerrahi müdahaleyi, hatta ooferektomi yapılmasını bile gerektirebilecek, hayatı tehtid eden bir komplikasyondur. Konjenital afibrinojenemi, nadir görülen bir konjenital kanama bozukluğudur. Asemptomatik olabileceği gibi, kanamaya meyil artışından, hayatı tehtid eden kanamalara kadar değişen çeşitli klinik belirtileri olabilmektedir. Konjenital afibrinojenemili hastalarda, ovulasyonu takiben intraabdominal kanama oldukça nadir görülmekte olup, korpus luteum rüptürüne bağlı hemoperitoneum tablosu sadece birkaç olguda bildirilmiştir. Biz, 28 yaşında, konjenital afibrinojenemi tanısı olan ve ovulasyonu takiben tekrarlayan masif hemoperitoneumu olan olguyu tartıştı. İlk kanama epizotu taze donmuş plazma, kriyopresipitat ve kan transfüzyonu ile tedavi edildi; ikinci kanama epizotunda tanısal laparomiye alınarak rüptüre folikül kisti çıkartıldı; üçüncü kanama epizotu taze donmuş plazma, kriyopresipitat ve kan transfüzyonu ile tedavi edildi; dördüncü kanama epizotunda tanısal laparatomiye alınarak să̆ salpingoooferektomi yapıldı; beşinci kanama epizotu ise taze donmuş plazma, kriyopresipitat ve kan transfüzyonu ile tedavi edildi. Konjenital kanama bozukluğu olan hastalarda konservatif yaklaşım çok önemlidir. $\mathrm{Bu}$ olgu göstermektedir ki; bu hastalarda ovaryan fonksiyonların korunması konservatif yaklaşımla mümkün olabilmektedir ve tekrarlayan kanamaların proflaksisinde ovulasyon süpresyonu önerilmelidir. J Turk Soc Obstet Gynecol 2014;4:242-5

Anahtar Kelimeler: Konjenital afibrinojenemi, rüptüre korpus luteum, hemoperitoneum

Çıkar Çatışması: Yazarlar bu makale ile ilgili olarak herhangi bir çıkar çatışması bildirmemişlerdir.

\section{Introduction}

Congenital afibrinogenemia is a rare, autosomal recessively inherited bleeding disorder which has an approximate incidence of $1 / 100.000$, and is generally seen in children born in consanguineous marriages( $(1)$. Fibrinogen is a glycoprotein synthesized from hepatocytes that has an important role in clot formation by turning into fibrin with the effect of thrombin. Fibrin provides the aggregation of thrombocytes by binding to glycoprotein IIb/IIIa on the surface of activated thrombocytes(2). Epistaxis, hemarthrosis, muscular hematoma, gastrointestinal

Address for Correspondence/Yazışma Adresi: Özhan Özdemir, MD,

Ankara Numune Education and Research Hospital, Clinic of Gynecology and Obstetrics, Ankara, Turkey

Phone: +90 3123252549 E-mail: seyozi@hotmail.com

Received/Geliş Tarihi : 22.11.2013

Accepted/Kabul Tarihi : 21.02.2014 
bleeding and menorrhagia are the most common symptoms in patients with afibrinogenemia, whereas massive intraabdominal bleeding due to ruptured corpus luteum has only been reported in a few cases(3-7). Even if this condition is rare in women with congenital bleeding disorders, it may be a lifethreatening complication even requiring oophorectomy(3). Herein, we report a patient with a five-time history of massive intraabdominal bleeding due to ruptured corpus luteum who had to be performed oophorectomy.

\section{Case}

A 28-year-old patient with a history of spontaneous abortion applied to our clinic with stomach ache, nausea and dizziness. The first clinical evaluation revealed hypotension (100/65 $\mathrm{mmHg}$ ) and tachycardia (97 beats/minute). She had guarding and rebound tenderness in abdominal exam with cervical sensitivity in pelvic exam. Her menstrual cycles were regular, and her last menstrual date was 18 days ago. She was learned to have gotten a diagnosis of congenital afibrinogenemia in early infancy. She had a history of twice laparotomies due to ruptured ovarian cysts; the first one was right ovarian cystectomy, and the second one was right oophorectomy about 4 years ago due to not having obtained hemostasis (Table 1).

Table 1. Chronologic bleeding episodes of the patient

\begin{tabular}{|c|c|c|c|c|c|}
\hline Bleeding Episode & $\begin{array}{l}\text { Hb level at } \\
\text { appliance } \\
\text { (gr/dl) }\end{array}$ & Ultrasonographic Findings & Treatment & Operation Observation & Transfusion \\
\hline $\begin{array}{l}\text { 1st Episode } \\
\text { (January 2007) }\end{array}$ & 7.5 & $\begin{array}{l}\text { Hemorrhagic cyst with a diameter } \\
\text { of } 28 \times 25 \mathrm{~mm} \text { arising from the } \\
\text { right ovary, prevalent free pelvic } \\
\text { fluid }\end{array}$ & $\begin{array}{l}\text { Expectant } \\
\text { Treatment }\end{array}$ & - & $\begin{array}{l}4 \text { U ES, } \\
12 \text { U FFP, } \\
4 \text { U Crioprecipitate }\end{array}$ \\
\hline $\begin{array}{l}\text { 2nd Episode } \\
\text { (March 2008) }\end{array}$ & 4.8 & $\begin{array}{l}\text { Hemorrhagic cyst with a diameter } \\
\text { of } 26 \times 23 \mathrm{~mm} \text { arising from the } \\
\text { right ovary, prevalent free pelvic } \\
\text { fluid }\end{array}$ & $\begin{array}{l}\text { Right ovary } \\
\text { cystectomy }\end{array}$ & $\begin{array}{l}\text { App. } 1500 \text { cc intraabdominal } \\
\text { hematoma and actively } \\
\text { bleeding corpus } \\
\text { hemorrhagicum cyst in the } \\
\text { right ovary }\end{array}$ & $\begin{array}{l}6 \text { U ES, } \\
12 \text { U FFP, } \\
4 \text { U Crioprecipitate }\end{array}$ \\
\hline $\begin{array}{l}\text { 3rd Episode } \\
\text { (June 2008) }\end{array}$ & 9.8 & $\begin{array}{l}\text { Hemorrhagic cyst with a diameter } \\
\text { of } 35 \times 27 \mathrm{~mm} \text { arising from the left } \\
\text { ovary, prevalent free pelvic fluid }\end{array}$ & $\begin{array}{l}\text { Expectant } \\
\text { Treatment }\end{array}$ & - & $\begin{array}{l}2 \text { U ES, } \\
14 \text { U FFP, } \\
4 \text { U Crioprecipitate }\end{array}$ \\
\hline $\begin{array}{l}\text { 4th Episode } \\
\text { (September 2009) }\end{array}$ & 5.5 & $\begin{array}{l}\text { Hemorrhagic cyst with a diameter } \\
\text { of } 41 \times 32 \mathrm{~mm} \text { arising from the } \\
\text { right ovary, prevalent free pelvic } \\
\text { fluid }\end{array}$ & $\begin{array}{l}\text { Right } \\
\text { Salpingo- } \\
\text { oophorectomy }\end{array}$ & $\begin{array}{l}\text { App. } 2000 \text { cc intraabdominal } \\
\text { hematoma and actively } \\
\text { bleeding corpus } \\
\text { hemorrhagicum cyst. As } \\
\text { hemostasis was not achieved, } \\
\text { salpingo-oophorectomy was } \\
\text { performed. }\end{array}$ & $\begin{array}{l}6 \text { U ES, } \\
12 \text { U FFP, } \\
5 \text { U Crioprecipitate }\end{array}$ \\
\hline $\begin{array}{l}5^{\text {th }} \text { Episode } \\
\text { (October 2013) }\end{array}$ & 9.9 & $\begin{array}{l}\text { Hemorrhagic cyst with a diameter } \\
\text { of } 32 \times 28 \mathrm{~mm} \text { arising from the left } \\
\text { ovary, prevalent free pelvic fluid }\end{array}$ & $\begin{array}{l}\text { Expectant } \\
\text { Treatment }\end{array}$ & - & $\begin{array}{l}2 \mathrm{U} \text { ES, } \\
16 \mathrm{U} \text { FFP, } \\
5 \mathrm{U} \\
\text { Crioprecipitate }\end{array}$ \\
\hline
\end{tabular}

She had been advised to use combined oral contraceptives following surgery however she quit using them about a month prior to her appliance to our hospital as she was planning to get pregnant.

The transvaginal ultrasonography revealed a $32 \times 28 \mathrm{~mm}$ hemorrhagic cyst with internal echogenity in the left ovary and prevalent intraabdominal fluid consistent with hematoma filling the whole pelvis being the deepest in the douglas pouch with a $35-\mathrm{mm}$ depth. We detected her hemoglobin $9.9 \mathrm{~g} / \mathrm{dl}$, thrombocytes $341.000 / \mu l$, fibrinogen 0 , and her INR, prothrombin time, and activated partial thromboplastin time were excessively long that they could not be measured as there was no coagulation. Owing to the hemoglobin level decreasing to $7.0 \mathrm{~g} / \mathrm{dl}$ in the control blood count after two hours along with tachycardia and symptomatic hypotension, we transfused her with 2 units of erythrocyte suspension (ES) and 6 units of fresh frozen plasma (FFP). During the time we closely followed the vital signs, we continued to replace with cryoprecipitate, FFP and ES until the hemostasis was achieved. We discharged the patient when she was hemodynamically stable and stopped bleeding, after an ultrasonographic control showing no hemoperitoneum. 


\section{Discussion}

Normally, intraperitoneal bleeding during ovulation does not cause a significant problem other than pelvic pain however in patients with congenital bleeding disorders or who use anticoagulants, it may lead to life-threatening conditions. The clinical case in congenital fibrinogen disorders may vary according to the level of fibrinogen deficiency. In congenital afibrinogenemia, no measurable level of fibrinogen is present. The patients typically start to bleed in the neonatal period, and, as in our case, $85 \%$ of them are diagnosed following an umblical cord bleeding(2). The severity of the bleeding and frequency of attacks vary among individuals. In afibrinogenemia, tendency to bleed vary widely even among patients with the same mutations, and a number of modified genes are accused of this $(8)$.

The most common clinical cases in congenital afibrinogenemia are umblical cord and superficial mucosal bleedings (particularly menorrhagia and epistaxis). Musculoskeletal system bleedings such as hemarthrosis may also be observed in approximately half of the patients. Less frequently, gastrointestinal, urinary and intracranial hemorrhages may be seen. Besides these spontaneous bleedings, hemorrhages following minor traumas or interventional procedures may also occur( $(9)$.

On the other hand, hemoperitoneum following a follicule rupture during ovulation is a rare but severe condition. A number of cases with coagulation disorders that were performed laparotomy, wedge resection of the ovaries, or even oophorectomy owing to hemoperitoneum due to ovulation or ruptured corpus luteum were reported in the literature(3). In our case, we had to perform oophorectomy as hemostasis could not be achieved. In patients with coagulation disorders, through management of the bleeding episodes diminishes the rate of unnecessary surgical procedures as well as helping to preserve fertility in these patients.

Spontaneous thrombotic complications were paradoxically reported in patients with afibrinogenemia. Normally, fibrin prevents thrombin production by decreasing the activation of prothrombin. However, as there is no fibrin in patients with afibrinogenemia, no antithrombin activity is present. As a result, prothrombin activation and thrombin production increase. Furthermore, free thrombin leads to the synthesis of a couple of growth factors from thrombocytes causing the proliferation of vascular smooth muscle cells and intimal hyperplasia. In association with all these anomalies, thrombotic complications may be observed in these patients(10).

The main approach in the treatment of bleeding episodes in patients with afibrinogenemia is to appropriately replace blood elements with fibrinogen, cryoprecipitate and FFP. In the management of spontaneous hemorrhages, target fibrinogen level is $>1 \mathrm{~g} / \mathrm{L}$ until hemostasis is achieved. The first choice for replacement should be fibrinogen concentrate in patients with afibrinogenemia. It is advantageous because it is virally inactive, its infusion volume is lower, and is less allergenic compared to other transfusion products. Cryoprecipitate and FFP may be alternatively chosen in emergent cases when fibrinogen concentrate cannot be obtained(11). In our case, we had to use FFP and cryoprecipitate for this same reason. Thrombotic complications such as deep venous thrombosis and pulmonary embolization were reported in patients with afibrinogenemia, and the risk is higher when cryoprecipitate is used as it also contains other coagulation factors. For this reason, some authors recommend low molecular weight heparin prophylaxis during replacement $(12)$.

The use of prophylactic fibrinogen concentrates is debatable as it has risks of thrombosis, viral infections, and anti-fibrinogen antibody formation, leading to the fact that prophylactic replacement should be individualized(13). Oral contraceptives are effective in preventing hemoperitoneum due to follicule rupture however they also increase the risk of thrombosis(6). Our case had had a history of combined oral contraceptive use until a month ago, and menstrual bleeding had been observed due to ovulation just after quitting them.

During pregnancy, replacement is recommended to decrease the risk of abortion, placental detachment and postpartum bleeding. As fibrinogen has a role in placental implementation, the risk of spontaneous abortion is increased in the first 6-8 weeks of pregnancy in patients with afibrinogenemia who are not being replaced. Even in patients who are being replaced, placental detachment risk was shown to be high(13).

\section{Conclusion}

Massive intraabdominal hemorrhage following ovulation is rare but may still be observed in patients with congenital bleeding disorders such as congenital afibrinogenemia. In the management of these hemorrhages, conservative approach plays an important role in order to preserve fertility. In these patients, suppression of ovulation by combined oral contraceptives is a recommendable approach in order to prevent repeating hemorrhages.

\section{References}

1. Tziomalos K, Vakalopoulou S, Perifanis V, Garipidou V. Treatment of congenital fibrinogen deficiency: overview and recent findings. Vasc Health Risk Manag 2009;5:843-8.

2. Acharya SS, Dimichele DM. Rare inherited disorders of fibrinogen. Haemophilia 2008;14(6):1151-8.

3. Cetinkaya SE, Pabuccu EG, Ozmen B, Dokmeci F. Recurrent massive hemoperitoneum due to ovulation as a clinical sign in congenital afibrinogenemia. Acta Obstet Gynecol Scand 2011;90(2):192-4.

4. Schneider D, Bukovsky I, Kaufman S, Sadovsky G, Caspi E. Severe ovarian hemorrhage in congenital afibrinogenemia. Acta Obstet Gynecol Scand 1981;60(4):431.

5. Bottini E, Pareti FI, Mari D, Mannucci PM, Muggiasca ML, Conti M. Prevention of hemoperitoneum during ovulation by oral contraceptives in women with type III von Willebrand disease and afibrinogenemia. Case reports. Haematologica 1991;76(5):431-3.

6. Castaman G, Ruggeri M, Rodeghiero F. Congenital afibrinogenemia: successful prevention of recurrent hemoperitoneum during ovulation by oral contraceptive. Am J Hematol 1995;49(4):363-4. 
7. Koussi A, Economou M, Athanasiou-Metaxa M. Intra-abdominal haemorrhage due to a ruptured corpus luteum cyst in a girl with congenital afibrinogenemia. Eur J Pediatr 2001;160(3):196-201.

8. de Moerloose P, Neerman-Arbez M. Treatment of congenital fibrinogen disorders. Expert Opin Biol Ther 2008;8(7):979-92.

9. Lak M, Keihani M, Elahi F, Peyvandi F, Mannucci PM. Bleeding and thrombosis in 55 patients with inherited afibrinogenaemia. $\mathrm{Br} \mathrm{J}$ Haematol 1999;107(1):204-6.

10. Oruc N, Tokat Y, Killi R, Tombuloglu M, Ilter T. Budd-Chiari syndrome in an afibrinogenemic patient: a paradoxical complication. Dig Dis Sci 2006;51(2):378-80.
11. Bolton-Maggs PH, Perry DJ, Chalmers EA, Parapia LA, Wilde JT, Williams MD, et al. The rare coagulation disorders - review with guidelines for management from the United Kingdom Haemophilia Centre Doctors' Organisation. Haemophilia 2004;10(5):593-628.

12. Haberer JP, Obstler C, Samama CM, Darnige L, Szwebel TA, Meyer A, et al. Postoperative deep venous thrombosis in a woman with congenital afibrinogenaemia treated with fibrinogen concentrates. Eur J Anaesthesiol 2008;25(6):519-21.

13. Kobayashi T, Kanayama N, Tokunaga N, Asahina T, Terao T. Prenatal and peripartum management of congenital afibrinogenemia. $\mathrm{Br} \mathrm{J}$ Haematol 2000;109(2):364-6. 